\title{
Roaring dynamics in rutting male red deer Cervus elaphus from five Russian populations
}

\author{
Ivan Yu. Rusin, Ilya A. Volodin*, Elena F. Sitnikova, Mikhail N. Litvinov, \\ Rimma S. Andronova \& Elena V. Volodina
}

\begin{abstract}
In Russia, current populations of Cervus elaphus sensu lato represent a mix of fragmented remnants of ancestral red deer naturally radiated from their center of origin in Middle Asia and populations, either re-stored by people at places where the native red deer are extinct or kept for agricultural production. Male rutting roaring activity represents an important part of red deer reproduction but there are no methods for unified evaluation of roaring dynamics. This study proposes the criteria for subdividing the entire rut period to phases (start, active, fading), applicable irrespectively to differences in population geographical area, animal density, subspecies or absolute values of call number per hour. With this approach, we estimate stag rutting roaring activity on hourly basis in five populations of red deer belonging to three subspecies by using two spaced automated recording devices per population, recording roars for $5 \mathrm{~min} /$ hour, $24 \mathrm{~h} /$ day, for 52-60 days of rutting period. Two spaced recorders per population provided similar data on rut dynamics, although absolute values of call number per hour were different. In four of the five study populations, rut period covered approximately the same calendar dates, from the last days of August until the last ten days of October. The mean roaring activity over a rut period differed strongly between populations (from 4$15 \mathrm{calls} / \mathrm{h}$ to $319-377 \mathrm{calls} / \mathrm{h}$ ). Effects of time of day on roaring activity differed between rut phases. The possible reasons of this variability are discussed.
\end{abstract}

How to cite this article: Rusin I.Yu., Volodin I.A., Sitnikova E.F., Litvinov M.N., Andronova R.S., Volodina E.V. 2021. Roaring dynamics in rutting male red deer Cervus elaphus from five Russian populations // Russian J. Theriol. Vol.20. No.1. P.44-58. doi: 10.15298/rusjtheriol.20.1.06.

KEY WORDS: automated recording, Cervus elaphus, passive acoustic monitoring, rut period, stag rutting calls; vocal activity.

Ivan Yu.Rusin [kikimos@yandex.ru],Department of Vertebrate Zoology, Faculty of Biology, Lomonosov Moscow State University, Vorobievy Gory, 1/12, Moscow 119234, Russia; Ilya A.Volodin [volodinsvoc@gmail.com],Department of Vertebrate Zoology, Faculty of Biology, Lomonosov Moscow State University, Vorobievy Gory, 1/12, Moscow 119234, Russia; Department of Behaviour and Behavioural Ecology of Mammals, A.N. Severtsov Institute of Ecology and Evolution, Russian Academy of Sciences, Moscow 119071, Russia; Elena F. Sitnikova [sitnikovae@yandex.ru], Bryansk Forest State Nature Reserve, Zapovednaya str. 2, Nerussa, Suzemsky District, Bryansk 242180, Russia; Mikhail N. Litvinov [mnlitvinov@rambler.ru], Komarov Ussuriisky State Nature Reserve, Far East Branch, Russian Academy of Sciences, Ussuriisk 692532, Russia; Rimma S. Andronova [rim.andronova@gmail.com], Federal State Institution "Zapovednoe Priamurye”, Kalinina str. 27b, Khabarovsk 680000, Russia; Elena V.Volodina [volodinsvoc@mail.ru], Department of Behaviour and Behavioural Ecology of Mammals, A.N. Severtsov Institute of Ecology and Evolution, Russian Academy of Sciences, Moscow 119071, Russia.

\section{Динамика рева во время гона у самцов благородного оленя Cervus elaphus пяти популяций России}

\author{
И.Ю. Русин, И.А. Володин*, Е.Ф. Ситникова, М.Н. Литвинов, \\ Р.С. Андронова, Е.В. Володина
}

РЕЗЮМЕ. Ныне живущие в России популяции Cervus elaphus sensu lato представляют собой фрагментированные популяции, возникшие в результате естественной радиации благородных оленей из центра происхождения в Средней Азии, а также искусственные популяции, которые либо были восстановлены человеком вместо истребленных естественных популяций либо содержатся для получения сельскохозяйственной продукции. Рев самцов оленей во время гона является важной частью их репродуктивного поведения, однако для оценки динамики гонного рева в популяциях нужны унифи-

* Corresponding author 
цированные методические подходы. В этом исследовании предложены критерии для подразделения всего периода гона на фазы (начальная, активная, затухание), применимые к разным популяциям оленей, вне зависимости от ареала, численности, подвидовой принадлежности и вокальной активности, выраженной в абсолютном числе криков в час. С помощью этого подхода мы оцениваем динамику активности гонного рева самцов на почасовой основе в пяти популяциях трех подвидов благородного оленя с помощью автоматических звукозаписывающих устройств, по два раздельно расположенных устройства на популяцию, записывающих ревы в течение 5 минут каждый час в течение суток на протяжении всего периода гона, длившегося от 52 до 60 дней в разных популяциях. Два раздельно расположенных устройства на популяцию предоставили сходные данные о динамике гона, хотя абсолютные величины числа криков в час различались. В четырех из пяти исследованных популяций гон происходил примерно в одни и те же календарные даты, с последних дней августа до третьей декады октября. Средняя активность рева за период гона сильно различалась между популяциями (от 4-15 криков в час до 319-377 криков в час). Влияние времени дня на активность рева различалось в зависимости от фазы гона. Вероятные причины такой изменчивости обсуждаются.

КЛЮЧЕВЫЕ СЛОВА: автоматизированная запись, Cervus elaphus, пассивный акустический мониторинг, период гона, гонные крики самцов, вокальная активность.

\section{Introduction}

Animal taxa with global distribution (e.g., sea gulls, auklets, ground squirrels, red deer) represent excellent models for highlighting the evolutionary changes underwent by populations during radiation from their ancestral centers of origin (Mahmut et al., 2002; Ludt et al., 2004; Liebers et al., 2004; Volodin et al., 2013a; Pshenichnikova et al., 2015; Matrosova et al., 2019). The evolutionary changes can be reflected in a complex of traits: morphological (Pshenichnikova et al., 2017), genetic (de Knijff et al., 2001; Mahmut et al., 2002; Liebers et al., 2004; Ludt et al., 2004; Matrosova et al., 2016), behavioural (Pshenichnikova et al., 2017) and acoustical (Volodin et al., 2013a; Matrosova et al., 2016; Pshenichnikova et al., 2017). In polygynous ungulates with impressive male courtship vocal displays, the evolutionary changes may also be reflected in the dynamic parameters of the rut: rut period timing, duration and vocal activity (Briefer et al., 2010; Bocci et al., 2013; Volodin et al., 2013b, 2015b; Yen et al., 2013; Enari et al., 2017; Rusin et al., 2019; Frey et al., 2020).

Male roaring activity during the rut represents an important part of reproduction in red deer and wapiti. During the rut, stags vocalize when compete with other stags for female harems. Acoustic traits of rutting calls advertise male quality (Reby \& McComb, 2003). Intensity and endurance of rutting vocal activity reflect male reproductive potential (Clutton-Brock \& Albon, 1979; Pepin et al., 2001; McPherson \& Chenoweth, 2012). Whereas estimating stag roaring activity is important for deer population management both in the wild and in captivity (Bocci et al., 2013; Yen et al., 2013; Volodin et al., 2015b; Enari et al., 2017; Rusin et al., 2019), there are no unified methods for timing the rut period and for quantitative estimation of male roaring activity.

In both red deer and wapiti, the acoustics of stag rutting calls differ between subspecies (Struhsaker, 1968; Nikol'skii et al., 1979; Bowyer \& Kitchen, 1987; Feighny et al., 2006; Kidjo et al., 2008; Frey et al., 2012; Bocci et al., 2013; Passilongo et al., 2013; Della Libera et al.,
2015; Volodin et al., 2015b, 2016a, 2019) but are similar between populations within subspecies irrespective of the management: captive, semi-captive or free-ranging (Volodin et al., 2015a; Golosova et al., 2017). At the same time, the absolute values of stag roaring activity may differ within population in the course of the rutting season (Volodin et al., 2013b, 2015b, 2016b) and between recording sites during the rutting season (Rusin et al., 2019). However, a methodical problem arises: how to document stag roaring activity in the course of the rut uniformly at a regular basis (Douhard et al., 2013). The focus of this study is on developing this methodical approach by using the automated recording devices.

Although all populations of the genus Cervus in Russia, according to their current formal taxonomical status, belong to four subspecies of Cervus elaphus, their taxonomy indeed is challenging and problematic. Populations which are native for the Asian part of Russia are represented by the Siberian wapiti Cervus elaphus sibiricus Severtzov, 1872 (Fedosenko, 1980; Kuznetsova et al., 2012; Volodin et al., 2013b) and by the Far East wapiti Cervus elaphus xanthopygus MilneEdwards, 1867 (Kuznetsova et al., 2012; Volodin et al., 2015b; Rusin et al., 2019). Populations occurring on the European part of Russia are represented by the native Caspian red deer Cervus elaphus maral Gray 1850 (Ludt et al., 2004; Trepet et al., 2017) and by the Cervus elaphus hippelaphus Erxleben, 1777 introduced from Germany (Likhatskij et al., 2012; Kuznetsova et $a l ., 2013)$. So far, detailed data on stag roaring activity throughout the rut are only available for a single population of Far East wapiti (Rusin et al., 2019). For other world red deer populations, for which published data on rut dynamics are available, they are incomplete, being either collected not on everyday basis or not for the entire rut period (Pepin et al., 2001; Reby et al., 2006; Bocci et al., 2013; Volodin et al., 2013b, 2015b).

Stag roaring activity can be tracked on an hourly basis for the entire rut period with a passive acoustic monitoring by using the automated recording devices, which record the target vocalizations (Volodin et al., 
$2013 b, 2015 b, 2016 b)$. In addition, the automated recording devices capture the sounds of non-target animals and the environmental noises, thus providing material for ecoacoustical monitoring of environment (Sugai et al., 2019). For evaluating male rutting vocal activity, the commonly used parameter is call rate, estimated as the mean number of calls/hour (Bocci et al., 2013; Rusin et al., 2019). Male red deer and wapiti roaring activity depends on the joint effects of time of day, temperature, speed of wind, humidity, precipitations, animal density, sex ratio and management (CluttonBrock \& Albon, 1979; Bowyer \& Kitchen, 1987; Pepin et al., 2001; Bocci et al., 2013; Douhard et al., 2013; Volodin et al., 2013b, 2015b). Due to these and others factors, stag roaring activity varies within a 24-hour cycle and in the course of the season (Clutton-Brock \& Albon, 1979; Bowyer \& Kitchen, 1987; Pepin et al., 2001; Reby et al., 2006; Bocci et al., 2013; Volodin et al., 2013b, 2015b, 2016b) as well as between seasons (Clutton-Brock \& Albon, 1979; Bocci et al., 2013). In addition, multiple peaks of estrus of hinds may prolong the rut (Guinness et al., 1971; Smith, 1994; García et al., 2002). Thus, absolute values of call number per hour can be strongly different along the rut depending on subspecies, population, population distribution area, animal density and recording site (Clutton-Brock \& Albon, 1979; Bocci et al., 2013; Volodin et al., 2016b; Rusin et al., 2019).

This study introduces and applies a potential approach for estimating vocal rutting activity throughout the rut period in different populations of red deer: from different parts of species distribution area, belonging to different subspecies and living at different social densities. In this study, we apply such approach for describing stag roaring activity in five red deer populations of Russia and reveal the effects of rut phase and time of day on the roaring activity. By comparison of data from two detached automated recorders per population, we also test, for each population, effects of recording site on the results.

\section{Materials and methods}

\section{Study populations and dates}

Stag rutting calls were collected in ten study sites in five populations of Cervus elaphus with automated recording devices in the autumnal rutting seasons of 2015-2017 (Tab. 1). Two of the studied populations (Belgorod and Bryansk) belong to subspecies C. e. hippelaphus Erxleben, 1777; one population (Kostroma) belongs to subspecies C. e. sibiricus Severtzov, 1872 and other two populations (Ussuri and Khabarovsk) belong to subspecies $C$. $e$. xanthopygus Milne-Edwards, 1867 (Tab. 1). Although material was not collected in the same rutting season, life conditions of the five study populations differed so strongly (Tab. 1), that this obviously overweighed the influence of the year of recording.

Both Belgorod and Bryansk populations initially originated from 10 German individual red deer released by Prince Oldenburg in his hunting facility in Russia at the end of 19th century, to restore the population of C. e. hippelaphus, which disappeared in Russia to that time because of extensive hunting (Likhatskij et al., 2012). From the Prince Oldenburg hunting facility, in which territory the Voronezh State Nature Reserve was created in 1927, the increased red deer population was distributed in 1960-1990 over the southern regions of Russia (Likhatskij et al., 2012). The Belgorod study population originated at 1971-1990 from 127 red deer individuals released at the territory "Russky les" (Likhatskij et al., 2012). The Bryansk study population originated at 1960-1980 from 164 individuals (Sitnikova \& Mishta, 2008). The subspecies status C.e. hippelaphus of the Belgorod and Bryansk populations has been established based on the mitochondrial DNA cytochrome b analysis (Kuznetsova et al., 2013).

The study population Kostroma originated in 2010 from a few dozen Siberian wapiti, translocated to the Kostroma farm (located on the European part of Russia) from their native grounds in the Altai region of Russia (Volodin et al., 2016b; Golosova et al., 2017). Status of this population as pure C. e. sibiricus was known because of its native origin. Native populations of Siberian wapiti are widespread at the western Asian part of Russia (Siberia), where these animals are numerous and either wild-living or bred for velvet antlers since the middle of 20th century (Lunitsin \& Borisov, 2012).

The study population Ussuri represented the wildliving Far East wapiti population of the Nature Reserve "Ussuriisky" and the Khabarovsk study population represented the wild-living Far East wapiti of the Nature Reserve "Bolshekhekhtsirsky" (both at Far East of Russia). Status of these populations as pure C. $e$. xanthopygus was known because both are the native populations of the local subspecies (Volodin et al., 2015b). Wild-living C. e. xanthopygus are common at Far East of Russia (Volodin et al., 2015b). Farming or semicaptive management are never applied to this subspecies.

\section{Acoustic recording}

For the automated acoustic recording of stag rutting calls, we used SongMeter SM2+ devices (Wildlife Acoustics Inc., Maynard, MA, USA), one in each recording site, two sites per population, five populations in total (Tab. 1). The devices were set to $22.05 \mathrm{kHz}$, 16 bit and stereo recording and were mounted on trees or pillars 2-4 $\mathrm{m}$ above the ground. Each device had two omnidirectional microphones, established horizontally at the angle of 180 degrees to each other. The recording sites within population were selected as the places of most active rut in previous seasons based either on previous observations of the authors or on reports of the staff of the localities. All devices remained on their places permanently for the entire rut period. People did not visit them during the rut, to avoid potential animal disturbance.

Each device recorded calls every day, the total length of acoustic monitoring was from 53 to $62 \mathrm{~d}$ depending on population (Tab. 1). The recording schedule was set 
Table 1. Sites of acoustic recording in the five study populations of Cervus elaphus (10 recording devices, one in each recording site, two devices \#1 and \#2 per population).

\begin{tabular}{|c|c|c|c|}
\hline $\begin{array}{l}\text { Location of two recording } \\
\text { sites (devices } \# 1 \text { and } \# 2 \text { ), } \\
\text { per population } \\
\end{array}$ & Population description & Recording dates & $\begin{array}{c}\text { Population area / Recording site } \\
\text { description }\end{array}$ \\
\hline $\begin{array}{l}\text { Belgorod\#1 } \\
(50.61581 \mathrm{~N}, 36.8849 \mathrm{E}) \\
\text { Belgorod } \# 2 \\
(50.6283 \mathrm{~N}, 36.87233 \mathrm{E}) \\
\text { between-device distance } \\
1.7 \mathrm{~km}\end{array}$ & $\begin{array}{l}\text { C. e. hippelaphus, about } 1500 \text { wild- } \\
\text { living individuals, introduced from } \\
\text { Germany (Likhatskij et al., 2012), } \\
\text { supplementary fed, hunted }\end{array}$ & $\begin{array}{l}30 \mathrm{Aug}-26 \mathrm{Oct} \\
2016,58 \mathrm{~d} \text { in total }\end{array}$ & $\begin{array}{l}\text { The } 20000 \text {-hectare unrestricted area } \\
\text { covered with forest, agriculture } \\
\text { fields and ravines. } \\
\text { \#1: Ravine covered with forest near } \\
\text { with large clearings, middle of the } \\
\text { northern slope. } \\
\# 2 \text { : Shallow ravine near the } \\
\text { agricultural field. }\end{array}$ \\
\hline $\begin{array}{l}\text { Bryansk\#1 } \\
(52.50246 \mathrm{~N}, 34.07683 \mathrm{E}) \\
\text { Bryansk\#2 } \\
(52.50852 \mathrm{~N}, 33.99277 \mathrm{E}) \\
\text { between-device distance } \\
5 \mathrm{~km}\end{array}$ & $\begin{array}{l}\text { C. e. hippelaphus, about } 70-90 \text { wild- } \\
\text { living individuals, introduced from } \\
\text { Germany (Likhatskij et al., 2012), } \\
\text { not supplementary fed, not hunted } \\
\text { (Sitnikova \& Mishta, 2006) }\end{array}$ & $\begin{array}{l}30 \text { Aug }-27 \text { Oct } \\
2016,59 \text { d in total. }\end{array}$ & $\begin{array}{l}\text { The 12186-hectare unrestricted area } \\
\text { of the "Bryansk Forest" Nature } \\
\text { Reserve. } \\
\# 1 \text { : A forested place at the edge of } \\
\text { a clearing. } \\
\# 2 \text { : A clearing of the forest near the } \\
\text { swamp. }\end{array}$ \\
\hline $\begin{array}{l}\text { Kostroma\#1 } \\
(58.40649 \mathrm{~N}, 43.25794 \mathrm{E}) \\
\text { Kostroma\#2 } \\
(58.40942 \mathrm{~N}, 43.25787 \mathrm{E}) \\
\text { between-device distance } \\
0.3 \mathrm{~km}\end{array}$ & $\begin{array}{l}\text { C. e. sibiricus, } 140 \text { farmed } \\
\text { individuals, including } 38 \text { stags, } \\
57 \text { hinds and } 45 \text { calves, originated } \\
\text { from animals translocated from the } \\
\text { Altai region of Russia (Volodin et } \\
\text { al., 2016b) }\end{array}$ & $\begin{array}{l}5 \mathrm{Sep}-5 \mathrm{Nov} \\
2015,62 \mathrm{~d} \text { in total. }\end{array}$ & $\begin{array}{l}\# 1 \& \# 2 \text { : the } 70 \text {-hectare enclosed } \\
\text { property covered by old gardens } \\
\text { and forest with large clearings. }\end{array}$ \\
\hline $\begin{array}{l}\text { Ussuri\#1 } \\
(43.65262 \mathrm{~N}, 132.66246 \mathrm{E}) \\
\text { Ussuri\#2 } \\
(43.63793 \mathrm{~N}, 132.6516 \mathrm{E}) \\
\text { between-device distance } \\
1 \mathrm{~km}\end{array}$ & $\begin{array}{l}\text { C. e. xanthopygus, about } \\
150 \text { wild-living individuals, native, } \\
\text { not supplementary fed, not hunted } \\
\text { (Litvinov 2008) }\end{array}$ & $\begin{array}{l}31 \text { Aug }-22 \text { Oct } \\
2015,53 \mathrm{~d} \text { in total }\end{array}$ & $\begin{array}{l}\text { The 40432-hectare unrestricted area } \\
\text { of the Ussuriisky Nature Reserve. } \\
\# 1 \text { : The elevation between two } \\
\text { small rivers, Suvorovka and } \\
\text { Koryavaya. } \\
\text { \#2: The valley of the Suvorovka } \\
\text { River, at the edge of a large } \\
\text { clearing. }\end{array}$ \\
\hline $\begin{array}{l}\text { Khabarovsk\#1 } \\
(48.14664 \mathrm{~N}, 134.84618 \mathrm{E}) \\
\text { Khabarovsk\#2 } \\
(48.11356 \mathrm{~N}, 134.85674 \mathrm{E}) \\
\text { between-device distance } \\
3 \mathrm{~km}\end{array}$ & $\begin{array}{l}\text { C. e. xanthopygus, about } \\
200 \text { wild-living individuals, native, } \\
\text { not supplementary fed, not hunted } \\
\text { (Letopis prirody, 2017) }\end{array}$ & $\begin{array}{l}23 \text { Aug }-22 \text { Oct } \\
2017,60 \mathrm{~d} \text { in total }\end{array}$ & $\begin{array}{l}\text { The } 45000 \text {-hectare unrestricted } \\
\text { area of Bolshekhekhtsirsky Nature } \\
\text { Reserve. } \\
\text { \#1: The cliff above the surrounding } \\
\text { forest. } \\
\# 2 \text { : The large clearing in the forest. }\end{array}$ \\
\hline
\end{tabular}

to record $5 \mathrm{~min}$ per hour, $120 \mathrm{~min}$ in total per 24-h cycle per device. In total, we obtained from $106 \mathrm{~h}$ to $124 \mathrm{~h}$ of acoustic recording per device, in total about $1200 \mathrm{~h}$ of recording in all the five populations.

Within population, the distance between two devices varied from $0.3 \mathrm{~km}$ to $5 \mathrm{~km}$ (Tab. 1). The devices were set at maximum possible sensitivity and potentially collected all stag rutting calls from the distance of about $1 \mathrm{~km}$. The rutting calls of Cervus elaphus propagate to a distance up to $1.5 \mathrm{~km}$, as it was shown by comparison of the same calls recorded automatically in a close vicinity of a stag caller and recorded manually at the distance of $1.5 \mathrm{~km}$ established by GPS-coordinates (Volodin et al., 2016b). To exclude even minor possibility of recording the same calls with two devices simultaneously, we desynchronized their working schedules within each hour. The first device started recording at the beginning of each hour, whereas the second one at the middle of each hour.

\section{Acoustic analyses}

Data for each device were treated separately. All sound files were viewed with Avisoft SASLab Pro software (Avisoft Bioacoustics, Germany, Berlin) main window (sampling rate $22.05 \mathrm{kHz}$, Hamming window, FFT 512, frame 100\%). The number of calls in each audio file irrespective of their quality was counted (Fig. 1). Some calls were faint and indistinguishable by ear from the background noise, but they were still detectable by spectrograms (Volodin et al., 2016b; Rusin et al., 2019). In total for the 10 devices from the five populations, we registered 111824 rutting calls (78023 at Belgorod, 12223 at Bryansk, 17955 at Kostroma, 926 at Ussuri, and 2697 at Khabarovsk). The automated recordings did not allow identifying individuals.

For each of the 10 recording devices, the daily mean call number/h for each 24 -h cycle was calculated as the total number of calls/d, divided by 24 , along 

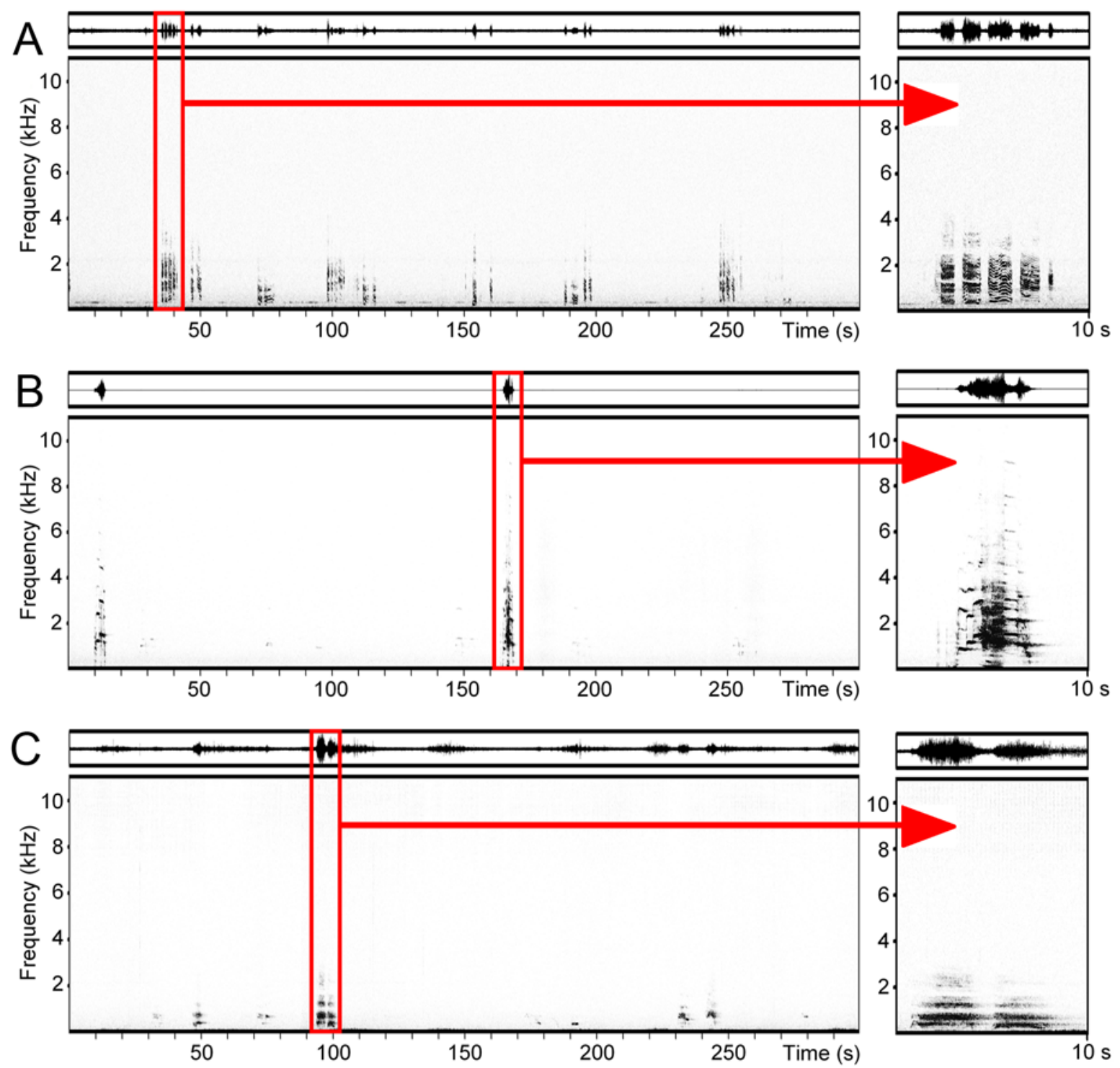

Fig. 1. Visualizing rutting calls of stags of different subspecies recorded with automated recording devices Song Meter SM2+. Axis X represents time in seconds; axis Y represents frequency in $\mathrm{kHz}$. Left: Spectrogram of a 5-min-long sound file. Right: Expanded spectrogram of the selected $10 \mathrm{~s}$ fragment. (A) C. e. hippelaphus of the Belgorod population, five rutting calls in the $10 \mathrm{~s}$ fragment, (B) C. e. sibiricus of the Kostroma population, one rutting call in the $10 \mathrm{~s}$ fragment, (C) C. e. xanthopygus of the Ussuri population, two rutting calls in the $10 \mathrm{~s}$ fragment.

the recording period, from 53 to $62 \mathrm{~d}$ depending on population (Tab. 1). For evaluating the hourly activity patterns of stag vocalizations, we calculated the mean number of calls/h for each time of day (averaged across the number of days of recording in each population). Similar calculations were done for each of the three phases of the rut (see below).

\section{Rut period timing}

For comparison of the roaring activity among each two recording sites within population and across the five study populations, we used the formal criteria for timing the rut onset and completion in each recording site (= each recording device). First, we determined the day with the maximum roaring activity (calls/h). Then, for each recording site, we selected the days of rut onset and completion as the days when call number/h reached $1 \%$ of the maximum (Fig. 2).

We also used the formal criteria for subdividing the entire rut period into three phases (start, active and fading). For each device, we calculated the mean call number/h across rut period from onset to completion (Fig. 2). We took the period between the day of rut onset and the day with mean call number/h as the start phase. We took the period between the two days with mean call number/h as the active phase. We took the period from the day with mean call number/h to the day of rut completion as the fading phase (Fig. 2). This approach 
rut onset

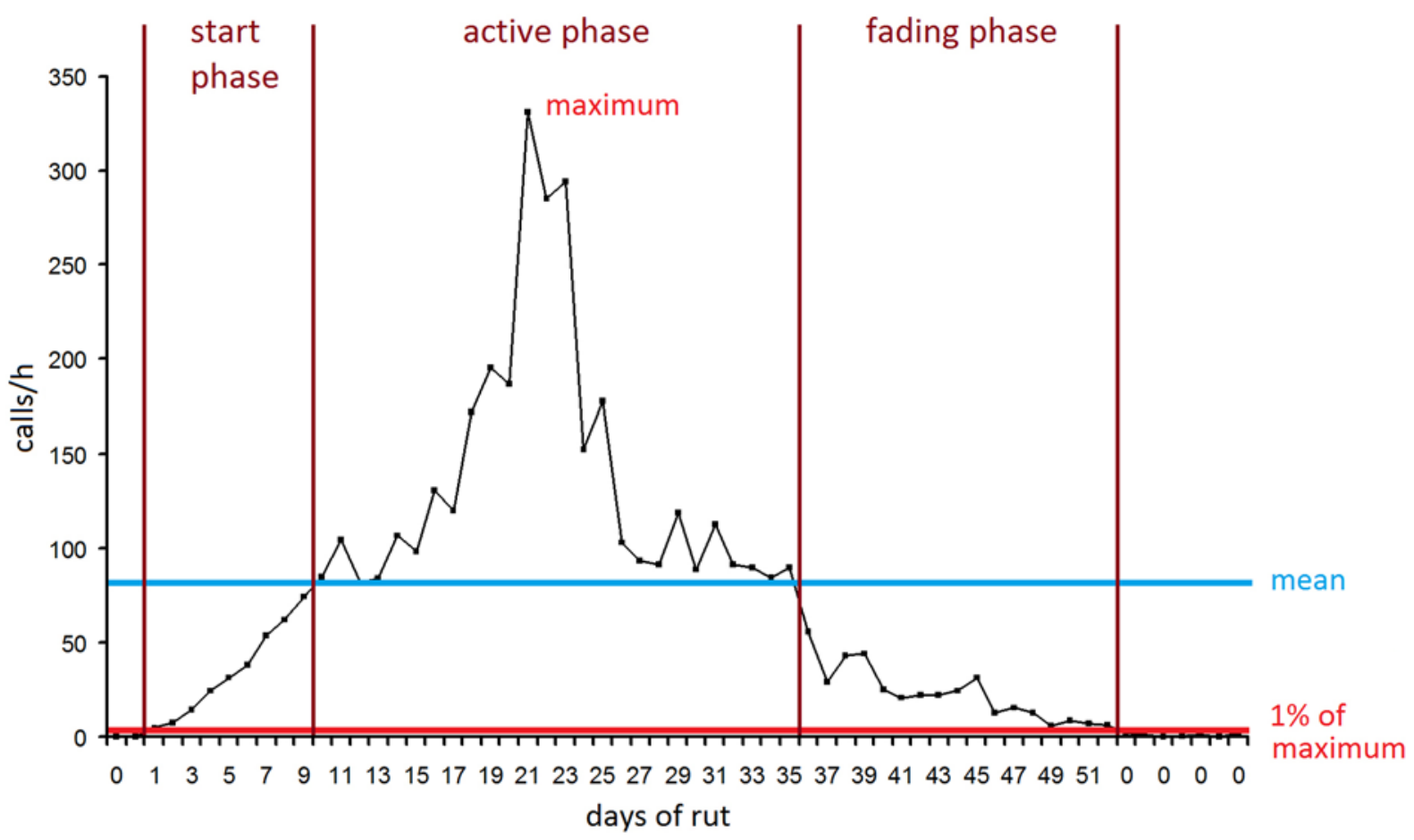

Fig. 2. Timing the onset and completion dates of rut period and subdividing the entire rut period into the three phases (start, active, fading). Maximum = the maximum roaring activity; mean $=$ the mean calls $/ \mathrm{h}$ across rut period from its onset to completion.

followed Bocci et al. (2013), also using the mean vocal activity as cut-off line for determining the peaking rut phase in red deer.

\section{Statistical analyses}

All statistical analyses were made with STATISTICA v. 8.0 (StatSoft Inc., Tulsa, OK, USA). Means are given as mean $\pm \mathrm{SE}$, all tests were two-tailed, and differences were considered significant whenever $p<0.05$. We used Pearson's correlation to compare the dynamics of roaring activity between recording sites within populations. We used one-way ANOVA to compare mean roaring activity between recording sites within populations for both the entire rut period and for the three phases of the rut. We used two-way ANOVA to estimate the effects of phase of the rut, time of day (hourly) and interaction effect of rut phase and time of day on the number of calls $/ \mathrm{h}$, taking time of day and phase of the rut as fixed factors. We used one-way ANOVA to estimate the effect of time of day (hourly) on the number of calls/h at the three phases of the rut.

We provided effect size (ES) statistics to measure the strength of an effect in addition to statistical significance. We calculated the effect size for ANOVA using $\eta^{2}\left(\eta^{2}=0.01\right.$ for a small effect, 0.06 for a medium effect and 0.14 for a large effect) (Cohen, 1992; Fritz et al., 2012).

\section{Results}

In four of the five study populations, rut period covered approximately the same calendar dates, from the last days of August until the last ten days of October (Tab. 2, Fig. 3). Rut period was the longest at Belgorod, Kostroma and Khabarovsk (51-56 d), intermediate at Ussuri (43-45 d) and the shortest at Bryansk (35-39 d). Exclusion was Bryansk, where the rut period was the shortest and completed on 8 October. The shortening of the rut period was due to either the shorter fading phase at Bryansk or to the shorter active phase at Ussuri (Tab. 2, Fig. 3). Across populations, the active phase of the rut lasted for about three weeks, from 8-19 September to the first days of October (Bryansk, Ussuri and Khabarovsk) or to the first ten days of October (Belgorod and Kostroma). The active phase of the rut and the roaring activity maximum were skewed towards the start of the rut at Kostroma, Ussuri and Khabarovsk, but at Belgorod and Bryansk they were skewed towards the completion of the rut (Tab. 2, Fig. 3). The roaring activity was the highest at Belgorod (mean 319-377 calls/h), intermediate at Bryansk and Kostroma (mean 51-117 calls/h) and the lowest at Khabarovsk and Ussuri (4-15 calls/h).

Whereas the devices within population displayed similar maximum and mean numbers of calls $/ \mathrm{h}$ at Belgorod, Kostroma and Khabarovsk, at Bryansk and Ussuri the maximum and mean numbers of calls $/ \mathrm{h}$ 


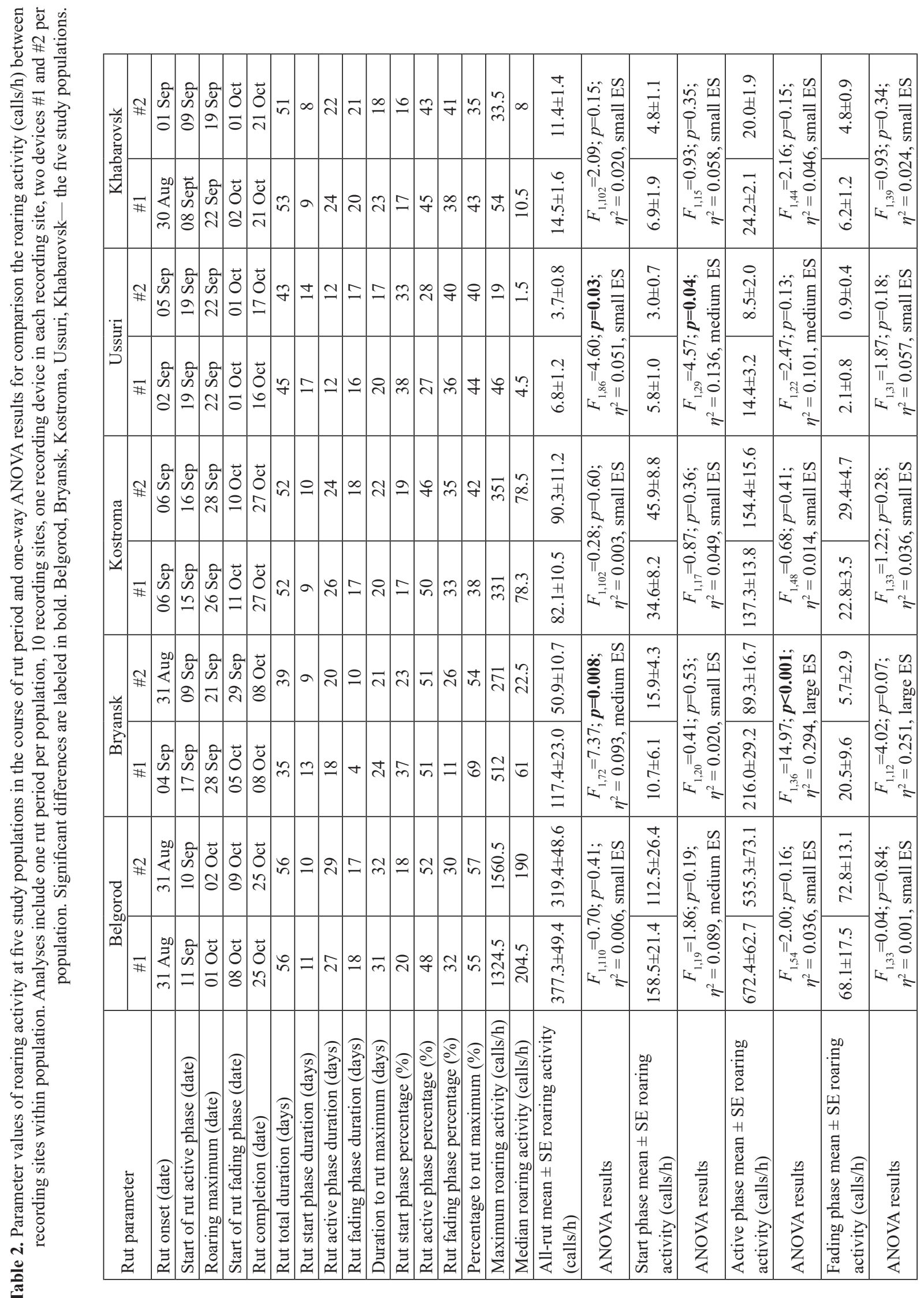



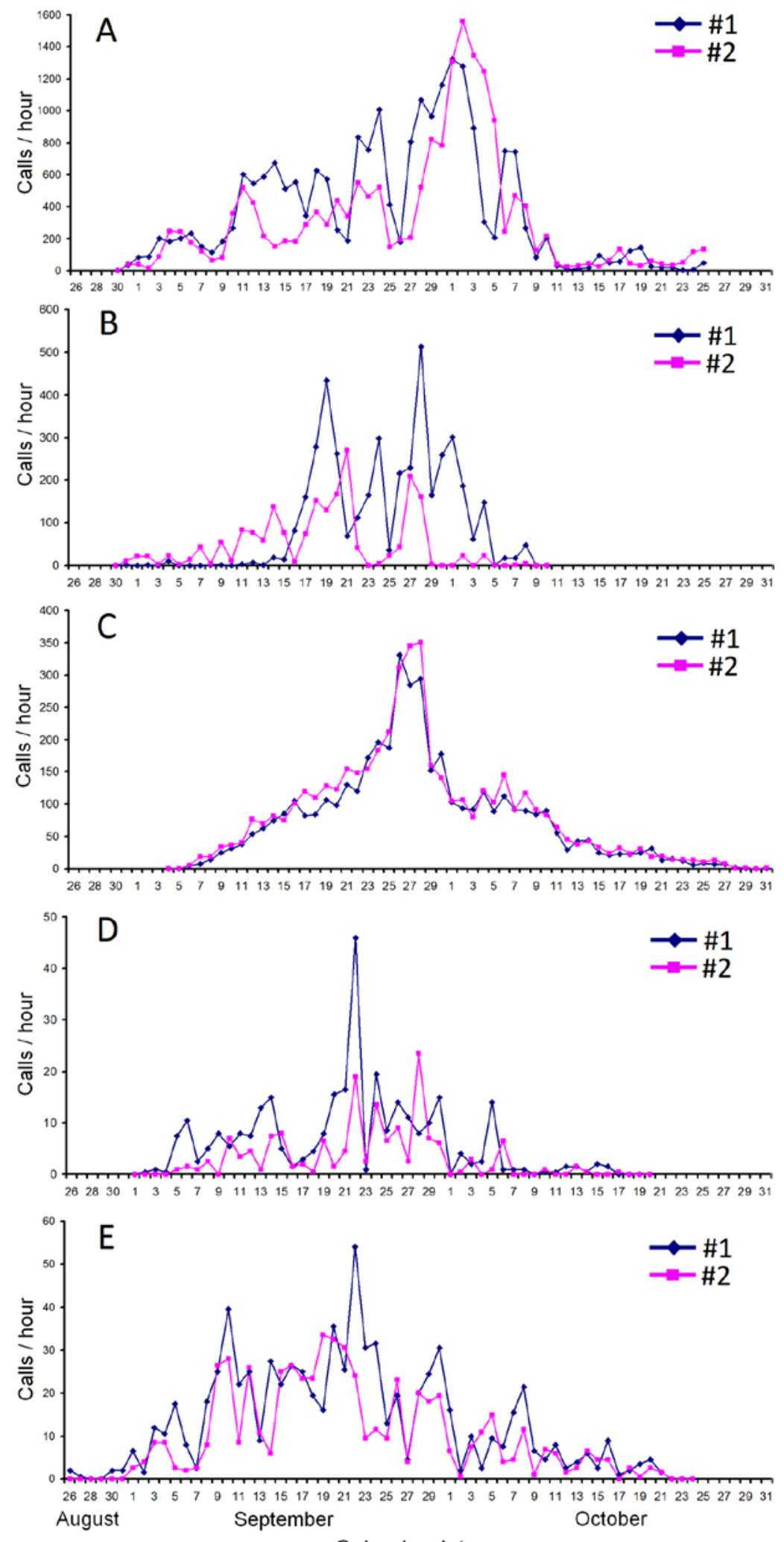

Calendar date

Fig. 3. The general dynamic of roaring activity in five study populations of Cervus elaphus: (A) Belgorod; (B) Bryansk; (C) Kostroma; (D) Ussuri; (E) Khabarovsk. \#1 and \#2: data from the two recording devices, one in each of the two recording sites per population. Calls/hour: the mean number of calls per hour per 24-h cycle. Please pay attention that dimensions of the ordinate axis are different for different populations. 
differed between two devices within population (Tab. 2). Estimation of effect size also indicated the strongest differences in Bryansk and the average differences in Ussuri, whereas in Belgorod, Kostroma and Khabarovsk, the differences were at minimal level (Tab. 2).

In all populations, the dynamic of roaring activity during the rut between two devices within population showed a significant positive correlation: Belgorod (from 31 Aug to 25 Oct, $r=0.718, p<0.001, n=56 \mathrm{~d}$ ), Bryansk (from 4 Sep to 8 Oct; $r=0.335, p<0.05, n=$ $35 \mathrm{~d}$ ), Kostroma (from 6 Sep to 27 Oct; $r=0.978, p<$ $0.001, n=52 \mathrm{~d}$ ), Ussuri (from 5 Sep to $16 \mathrm{Oct} ; r=0.615$, $p<0.001, n=42 \mathrm{~d}$ ), Khabarovsk (from 1 Sep to 21 Oct; $r=0.730, p<0.001, n=51 \mathrm{~d})$. The highest correlation was found at Kostroma, whereas the weakest (although significant) at Bryansk. Probably, the value of correlation depended on the distance between the acoustic devices, being the least in Kostroma $(0.3 \mathrm{~km})$ and the largest in Bryansk (5 km) (Tab. 1).

The mean hourly number of calls/h per time of day differed between populations (Fig. 4). For all populations with the exclusion of Kostroma, we found a substantial decrease of roaring activity in light time of day, from about hours 09:00 to 17:00-18:00. The roaring maximum was achieved between hours 01:00 and 03:00 at Bryansk, Ussuri and Khabarovsk, and between hours 05:00 and 06:00 at Belgorod and Kostroma. Additional two peaks of roaring activity were the early-morning peak before sunrise (between hours 05:00 and 07:00 for different populations) and the late-evening peak after sunset (between hours 17:00 and 18:00 for Kostroma and between hours 19:00 and 21:00 for Belgorod, Bryansk, Ussuri and Khabarovsk) (Fig. 4). The roaring activity, for the exclusion of Kostroma, faded steadily for a few hours after sunrise, but only very rarely started before sunset. Within population, different recording sites displayed very similar dynamics of the number of roars during 24-h cycle, whereas the differences were well expressed between populations.

We estimated the effects of rut phase, time of day (hourly) and interaction effect of rut phase and time of day on the number of calls/h (Tab. 3). For all the five populations, the number of calls/h depended strongly on the rut phase and time of day. As the effect of rut phase on the number of calls/h was prominent, we additionally analysed the relationship between the number of calls/h and time of day separately for each rut phase for each recording site of each population (Tab. 4). We found that the dependence between the number of calls/ $h$ and time of day was substantially more prominent at the active phase than either at the start or fading phases (Tab. 4). For the active phase, we found perfectly coinciding results between two recording sites within populations, whereas for the start and fading phases, the results between two recording sites within population could differ (Tab. 4).

\section{Discussion}

This study of five populations of Cervus elaphus of Russia introduces the formal criteria for determining rut onset, completion and applies the three rutting phases: start, active and fading. Days of rut onset and completion were established when call number/h reached $1 \%$ of the maximum roaring activity. Subdividing the rutting period into three phases was based on the mean call number/h from rut onset to completion. This approach enabled to compare the roaring activity in the five study populations living at strongly different climate zones, differing in calendar dates of the rut and in rut duration. Our results on rut dynamics in five populations of Russia provide referential information for further passive acoustic monitoring and population management (Volodin et al., 2015b, 2016b).

Potentially, these formal criteria can be expanded to other Cervidae species displaying male rutting vocal activity, as fallow deer Dama dama (Briefer et al., 2010), sika deer Cervus nippon (Yen et al., 2013; Enari et al., 2017) and to Bovidae species, producing impressive vocal displays throughout rutting period, as e.g. impala Aepyceros melampus (Frey et al., 2020). Our data can be valuable for managers of natural reserves and hunting facilities for preparing the schedules of the ecoacoustical excursions and hunting games using the hunting luring instruments during the rut (Volodin et al., 2013b). In semi-captive populations of Siberian wapiti kept for velvet antlers, as Kostroma population in our study, the knowledge of timing of the rut in previous years enables to plan e.g. releasing of the older and younger stags to the herd before the rut as well as pre-winter separation of females and the young after the rut (Sibiryakova et al., 2018). In the Ussuri populations, the reference data on stag rutting activity at different recording sites can be used for planning the every-year human counts of roaring stags by ear. In addition, data provide reference information for estimating the effect of climate changes on the shifts in rut period timing in the study sites in the following years, in comparison with data from the meteorological stations, nearest to the recording sites.

Two recording sites within population provide similar data on the dynamics of roaring activity over the entire rut period. Differences in the actual values of stag roaring activity between sites within populations may reflect the differences in use of these sites by stags during the rut. The inter-device distance affects the coincidence of data on dynamics of roaring activity, as the stronger correlation was obtained for the population in which the devices are closest. The reason can be in transitions of stags over the territory during the rut (Clutton-Brock \& Albon, 1979; Fedosenko, 1980), so that the closest devices can capture calls in the same male. Between populations, the differences in the dynamics and in the actual values of stag roaring activity were much more prominent.

Between populations, the roaring activity over a rut period differed strongly (up to 50 times), ranging from 4-7 calls/h at Ussuri to 319-377 calls/h at Belgorod. This could be due to many factors, primarily the local population density. In this study, the largest population density was in Kostroma (Tab. 1). For the exclusion of this captive population, among the natural populations 

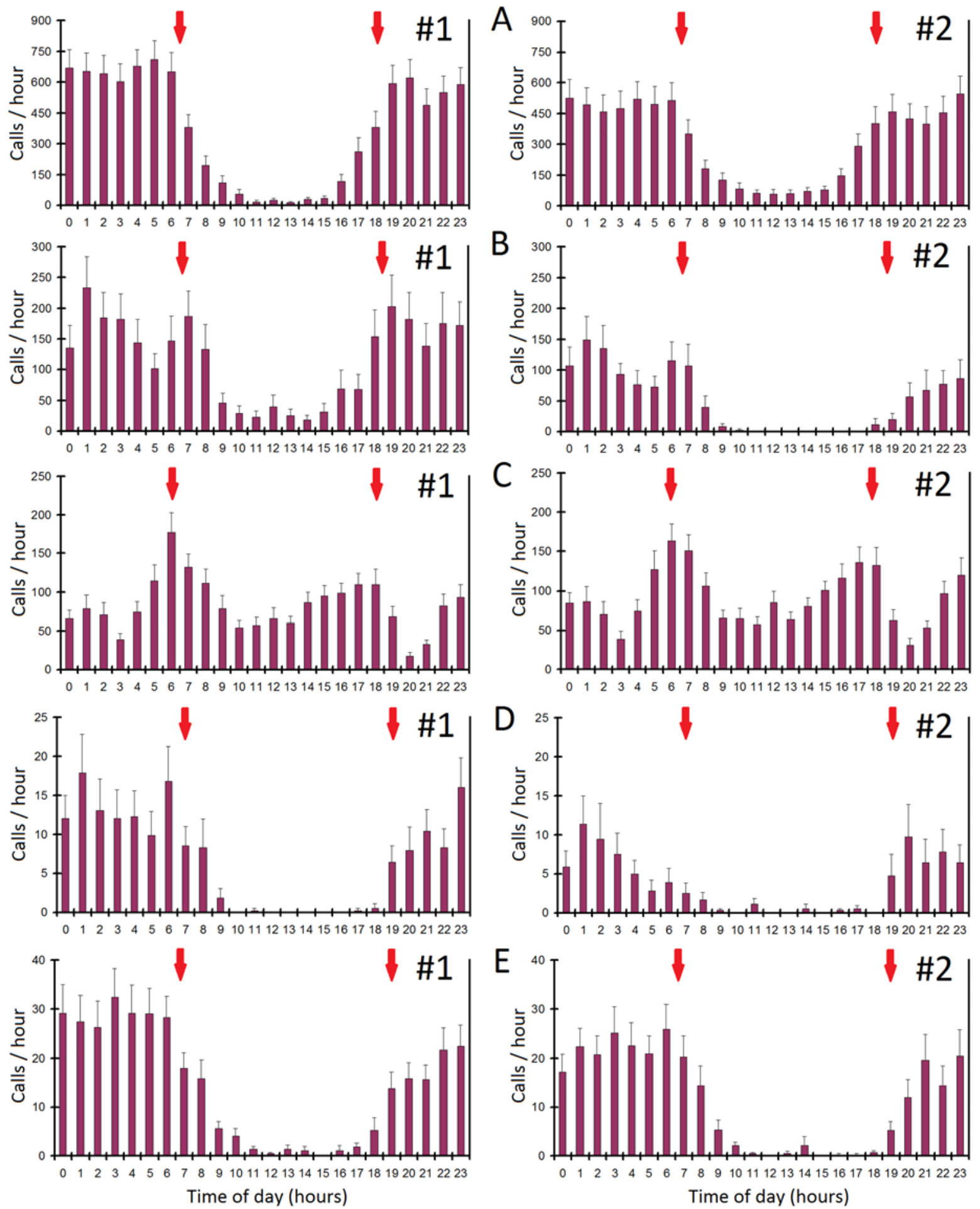

Fig. 4. Time of day (hourly) graphs of stag roaring activity in the five populations of Cervus elaphus: (A) Belgorod; (B) Bryansk; (C) Kostroma; (D) Ussuri; (E) Khabarovsk. \#1 and \#2 - two recording devices per population, one in each recording site. Calls/h: the mean number of calls per time of day (averaged across the number of days per rut period, from 53 to $62 \mathrm{~d}$ depending on population); whiskers indicate SE. For each recording site, the time of sunrise and sunset for the day with the maximum roaring activity are indicated by arrows. Please pay attention that dimensions of the axes are different for different populations. 
Table 3. Effects of rut phase, time of day (hourly) and interaction effect of rut phase and time of day on the number of calls/h at five populations and 10 recording sites (two recording sites per population). Significant differences are labeled in bold.

\begin{tabular}{|l|c|c|c|c|}
\hline \multicolumn{1}{|c}{ Population } & $\begin{array}{c}\text { Recording } \\
\text { sites }\end{array}$ & Rut phase & Time of day (hourly) & $\begin{array}{c}\text { Rut phase \& } \\
\text { Time of day (hourly) }\end{array}$ \\
\hline \multirow{3}{*}{ Belgorod } & $\# 1$ & $F_{2,1272}=395.80 ; \boldsymbol{p}<\mathbf{0 . 0 0 1}$ & $F_{23,1272}=17.87 ; \boldsymbol{p}<\mathbf{0 . 0 0 1}$ & $F_{46,1272}=7.99 ; \boldsymbol{p}<\mathbf{0 . 0 0 1}$ \\
\cline { 2 - 6 } & $\# 2$ & $F_{2,1272}=174.21 ; \boldsymbol{p}<\mathbf{0 . 0 0 1}$ & $F_{23,1272}=5.29 ; \boldsymbol{p}<\mathbf{0 . 0 0 1}$ & $F_{46,1272}=2.33 ; \boldsymbol{p}<\mathbf{0 . 0 0 1}$ \\
\hline \multirow{3}{*}{ Bryansk } & $\# 1$ & $F_{2,768}=144.07 ; \boldsymbol{p}<\mathbf{0 . 0 0 1}$ & $F_{23,768}=1.84 ; \boldsymbol{p}<\mathbf{0 . 0 1}$ & $F_{46,768}=2.02 ; \boldsymbol{p}<\mathbf{0 . 0 0 1}$ \\
\cline { 2 - 6 } & $\# 2$ & $F_{2,864}=48.45 ; \boldsymbol{p}<\mathbf{0 . 0 0 1}$ & $F_{23,864}=3.00 ; \boldsymbol{p}<\mathbf{0 . 0 0 1}$ & $F_{46,864}=2.08 ; \boldsymbol{p}<\mathbf{0 . 0 0 1}$ \\
\hline \multirow{3}{*}{ Kostroma } & $\# 1$ & $F_{2,1176}=233.17 ; \boldsymbol{p}<\mathbf{0 . 0 0 1}$ & $F_{23,1176}=3.89 ; \boldsymbol{p}<\mathbf{0 . 0 0 1}$ & $F_{46,1176}=1.85 ; \boldsymbol{p}<\mathbf{0 . 0 0 1}$ \\
\cline { 2 - 6 } & $\# 2$ & $F_{2,1176}=245.48 ; \boldsymbol{p}<\mathbf{0 . 0 0 1}$ & $F_{23,1176}=4.68 ; \boldsymbol{p}<\mathbf{0 . 0 0 1}$ & $F_{46,1176}=2.22 ; \boldsymbol{p}<\mathbf{0 . 0 0 1}$ \\
\hline \multirow{3}{*}{ Ussuri } & $\# 1$ & $F_{2,1008}=45.66 ; \boldsymbol{p}<\mathbf{0 . 0 0 1}$ & $F_{23,1008}=7.25 ; \boldsymbol{p}<\mathbf{0 . 0 0 1}$ & $F_{46,1008}=2.00 ; \boldsymbol{p}<\mathbf{0 . 0 0 1}$ \\
\cline { 2 - 6 } & $\# 2$ & $F_{2,960}=29.52 ; \boldsymbol{p}<\mathbf{0 . 0 0 1}$ & $F_{23,960}=4.14 ; \boldsymbol{p}<\mathbf{0 . 0 0 1}$ & $F_{46,960}=1.86 ; \boldsymbol{p}<\mathbf{0 . 0 0 1}$ \\
\hline \multirow{3}{*}{ Khabarovsk } & $\# 1$ & $F_{2,1200}=86.68 ; \boldsymbol{p}<\mathbf{0 . 0 0 1}$ & $F_{23,1200}=7.97 ; \boldsymbol{p}<\mathbf{0 . 0 0 1}$ & $F_{46,1200}=2.97 ; \boldsymbol{p}<\mathbf{0 . 0 0 1}$ \\
\cline { 2 - 6 } & $\# 2$ & $F_{2,1152}=72.16 ; \boldsymbol{p}<\mathbf{0 . 0 0 1}$ & $F_{23,1152}=6.34 ; \boldsymbol{p}<\mathbf{0 . 0 0 1}$ & $F_{46,1152}=2.44 ; \boldsymbol{p}<\mathbf{0 . 0 0 1}$ \\
\hline
\end{tabular}

Table 4. Effects of time of day (hourly) on the number of calls/h at the three rut phases for five populations and 10 recording sites (two recording sites per population). Significant values are labeled in bold.

\begin{tabular}{|l|c|c|c|c|}
\hline \multicolumn{1}{|c}{ Population } & $\begin{array}{c}\text { Recording } \\
\text { sites }\end{array}$ & Rut start phase & Rut active phase & Rut fading phase \\
\hline \multirow{3}{*}{ Belgorod } & $\# 1$ & $F_{23,240}=8.31 ; \boldsymbol{p}<\mathbf{0 . 0 0 1}$ & $F_{23,624}=23.22 ; \boldsymbol{p}<\mathbf{0 . 0 0 1}$ & $F_{23,408}=3.29 ; \boldsymbol{p}<\mathbf{0 . 0 0 1}$ \\
\cline { 2 - 5 } & $\# 2$ & $F_{23,216}=4.72 ; \boldsymbol{P}<\mathbf{0 . 0 0 1}$ & $F_{23,672}=7.74 ; \boldsymbol{P}<\mathbf{0 . 0 0 1}$ & $F_{23,384}=1.77 ; \boldsymbol{p}=\mathbf{0 . 0 2}$ \\
\hline \multirow{3}{*}{ Bryansk } & $\# 1$ & $F_{23,288}=0.97 ; p=0.50$ & $F_{23,408}=5.18 ; \boldsymbol{p}<\mathbf{0 . 0 0 1}$ & $F_{23,72}=0.90 ; p=0.60$ \\
\cline { 2 - 6 } & $\# 2$ & $F_{23,192}=1.94 ; \boldsymbol{p}=\mathbf{0 . 0 0 8}$ & $F_{23,456}=5.65 ; \boldsymbol{p}<\mathbf{0 . 0 0 1}$ & $F_{23,216}=1.20 ; p=0.25$ \\
\hline \multirow{3}{*}{ Kostroma } & $\# 1$ & $F_{23,192}=1.42 ; P=0.10$ & $F_{23,600}=5.68 ; \boldsymbol{P}<\mathbf{0 . 0 0 1}$ & $F_{23,384}=4.55 ; \boldsymbol{P}<\mathbf{0 . 0 0 1}$ \\
\cline { 2 - 6 } & $\# 2$ & $F_{23,216}=2.07 ; \boldsymbol{p}=\mathbf{0 . 0 0 4}$ & $F_{23,552}=5.47 ; \boldsymbol{p}<\mathbf{0 . 0 0 1}$ & $F_{23,408}=3.71 ; \boldsymbol{p}<\mathbf{0 . 0 0 1}$ \\
\hline \multirow{3}{*}{ Ussuri } & $\# 1$ & $F_{23,384}=2.56 ; \boldsymbol{p}<\mathbf{0 . 0 0 1}$ & $F_{23,264}=3.44 ; \boldsymbol{p}<\mathbf{0 . 0 0 1}$ & $F_{23,360}=1.41 ; \boldsymbol{p}=0.10$ \\
\cline { 2 - 6 } & $\# 2$ & $F_{23,312}=1.27 ; p=0.18$ & $F_{23,264}=2.35 ; \boldsymbol{p}<\mathbf{0 . 0 0 1}$ & $F_{23,384}=1.59 ; \boldsymbol{p}=\mathbf{0 . 0 4}$ \\
\hline \multirow{3}{*}{ Khabarovsk } & $\# 1$ & $F_{23,192}=1.76 ; \boldsymbol{p}=\mathbf{0 . 0 2}$ & $F_{23,552}=9.51 ; \boldsymbol{p}<\mathbf{0 . 0 0 1}$ & $F_{23,456}=3.14 ; \boldsymbol{p}<\mathbf{0 . 0 0 1}$ \\
\cline { 2 - 5 } & $\# 2$ & $F_{23,168}=2.14 ; \boldsymbol{p}=\mathbf{0 . 0 0 3}$ & $F_{23,504}=6.91 ; \boldsymbol{p}<\mathbf{0 . 0 0 1}$ & $F_{23,480}=3.93 ; \boldsymbol{p}<\mathbf{0 . 0 0 1}$ \\
\hline
\end{tabular}

the population density was the highest in Belgorod and the lowest in Khabarovsk and Ussuri, in coincidence with the value of all-rut mean roaring activity, which was the maximal in Belgorod and the minimal in Ussuri. The density at recording sites could also depend on supply and distribution of supplementary feeding (SánchezPrieto et al., 2004; Pérez-González et al., 2010) available in Kostroma and Belgorod and lacking in other study populations.

Subspecies of a monitored population could also affect the roaring activity, because wild-living Siberian and Far East wapiti normally do not have the rutting aggregations (Fedosenko, 1980; Volodin et al., 2013b, 2015b; Golosova et al., 2017). At the same time, the rutting aggregations are characteristic for the European subspecies of red deer (Clutton-Brock \& Albon, 1979; Sánchez-Prieto et al., 2004; Douhard et al., 2013). For example, in wild-living populations of European subspecies of red deer, the rutting roaring activity reaches 400 calls/h at the period of most active rut (Bocci et al., 2013) or reaches 200 calls/h at the peak of a 24 -h-cycle rutting roaring activity (Clutton-Brock \& Albon, 1979; Bocci et al., 2013). These values were approximately the same as were obtained in this study for Bryansk population, which is representative of European red deer population without providing the supplementary feeding.

Although some study populations were separated by many thousand kilometers, in all free-ranging populations (four out of five) the roaring peaked between hours 03:00 and 06:00, nearly lacked between 10:00 and 18:00, steadily increased from 20:00 to 03:00 to maximum and then rapidly decreased from 06:00 to 09:00 to minimum. A single captive population in this study (Kostroma) differed strongly by the hourly roaring activity during a 
24-h cycle from other populations. Primarily difference was the absence of the nocturnal peak of roaring activity due to the continuous roaring in the light time of day. This could be due the effect of farming on a restricted territory, without a possibility for animals to leave a centre of rutting activity along to providing food regularly in the light time of day. Providing food regularly on some deer farms (as Kostroma) and in hunting facilities provokes hinds to move to the food sources and evokes an enhanced arousal of stags, trying to control the female harems (Sánchez-Prieto et al., 2004; Pérez-González et al., 2010; Golosova et al., 2017).

At rutting season of 2013, stag roaring activity in Kostroma population displayed the same pattern of peaks as sunset and sunrise and relatively low roaring activity in the dark time (Volodin et al., 2016b). At the same time, the actual values of roaring activity increased 10 times between seasons of 2013 and 2015 (Volodin et al., 2016b and this study). This prominent increase of roaring activity could be due to the time space passed since translocation (three years to the 2013 rutting season and five years to the 2015 rutting season), so the young stags became older and the total number of adults in the herd also increased.

Supplementary feeding was practiced also at Belgorod, however, the Belgorod population is free ranging distinctive to Kostroma population. This could be the reason why stag roaring dynamic in Belgorod was closer to those observed in the populations of natural reserves (Bryansk, Ussuri, Khabarovsk) than to those in the farmed Kostroma population. At Ussuri population, data of the rutting season of 2014 (at active phase) were very similar with data of this study by the lack of calls in the middle of the day and by well-expressed peak of nocturnal activity, at approximately the same absolute values of rutting calls/h (Volodin et al., 2015b).

However, the higher vocal activity during the light time of day compared to the night time is characteristic not only for farmed red deer (Pepin et al., 2001), but also reported for a wild-living population of C. e. scoticus on the Rhum Island (Clutton-Brock \& Albon, 1979). At the same time, a semi-captive population of $C$. e. sibiricus displays a usual relationship of roaring activity with time of day, with three peaks, at sunrise, at sunset and in the middle of the night (Volodin et al., 2016b), similar to the wild-living Alpine population C. e. hippelaphus (Bocci et al., 2013). General factors and mechanisms that lead to nocturnal or diurnal vocal activity of red deer have yet to be studied.

In addition, the start of rutting roaring of Cervidae species can be considered as a seasonal key marker for creating false color spectrograms of the acoustic landscapes (soundscapes) in frames of a modern ecoacoustical approach using big-data analysis for tracking the changes in the acoustic environment (Ferreira et al., 2018; Lillis et al., 2018; Towsey et al., 2018; Sugai et al., 2019). Calls of mammals are often considered among the key markers for describing the acoustic landscapes (soundscapes) (Ferreira et al., 2018; Farina, 2019), in addition to the key markers of insect, anuran, bat or bird choruses (Jeliazkov et al., 2016; Gasc et al., 2017; Doohan et al., 2019; Desjonquères et al., 2020), because many mammalian species produce high-amplitude long-distance vocalizations, representing important bioacoustical components of the environment: lion Panthera leo (McComb et al., 1994), maned wolf Chrysocyon brachyurus (Balieiro \& Monticelli, 2019) and red deer (Bocci et al., 2013; Douhard et al., 2013; Volodin et al., 2013b, 2015b; Rusin et al., 2019).

As two recording sites within population provide similar data on the dynamics of roaring activity, we can conclude that one recording device/site per population is sufficient for population passive acoustic monitoring at least in small natural habitats and in enclosures. At the same time, two or even more remotely spaced devices may be necessary for the large territories. We also can conclude that whereas a position of the recording site within population area does not affect noticeably the roaring dynamics, it may nevertheless strongly affect the actual number of recorded calls. Effects of time of day on roaring activity depended on phase of the rut and were similar in all populations.

Future passive acoustic monitoring of Cervus elaphus populations at the same recording sites in the following seasons should confirm the sustainable or shifted calendar dates of the rut and variation in absolute numbers of calls/h within and between populations. Further research is necessary to estimate the effect of different natural factors on the roaring activity: temperature, humidity, power of wind, cloudiness, atmosphere pressure, precipitations.

ACKNOWLEDGMENTS. This study has been conducted in collaboration with the staff of the facilities and nature reserves, in accordance with their red deer and wapiti research projects and with guidelines of the staff regarding animal welfare. In all deer facilities, animal disturbance was kept at minimum, as the recording has been conducted automatically in the absence of people. Data for this study were collected noninvasively in accordance with the Guidelines for the Use of Animals in Research (Animal Behaviour, 2006, 71: 245-253). We thank the staff and owners of study facilities for their help and support during the data collection. We thank Olga Sibiryakova for her help with data collecting and transporting. We thank Nina Vasilieva and Sergey Ogurtsov for the consulting with statistics. The study was supported by the Russian Foundation for Basic Research, grant 19-04-00133.

\section{References}

Balieiro F. \& Monticelli P.F. 2019. Evidence of individual discrimination in the maned wolf long-distance extendedbark // Behavioural Processes. Vol.158. P.219-227.

Bocci A., Telford M. \& Laiolo P. 2013. Determinants of the acoustic behaviour of red deer during breeding in a wild alpine population, and implications for species survey // Ethology, Ecology \& Evolution. Vol.25. P.52-69. 
Bowyer T.R. \& Kitchen D.W. 1987. Sex and age-class differences in vocalization of Roosevelt elk during rut // American Midland Naturalist. Vol.118. P.225-235.

Briefer E., Vannoni E. \& McElligott A.G. 2010. Quality prevails over identity in the sexually selected vocalisations of an ageing mammal // BMC Biology. Vol.8. No.35. P.1-15.

Clutton-Brock T.H. \& Albon S.D. 1979. The roaring of red deer and the evolution of honest advertising // Behaviour. Vol.69. P.145-170.

Cohen J. 1992. A power primer // Psychological Bulletin. Vol.112. No.1. P.155-159.

de Knijff P., Denkers F., van Swelm N.D. \& Kuiper M. 2001. Genetic affinities within the herring gull Larus argentatus assemblage revealed by AFLP genotyping // Journal of Molecular Evolution. Vol.52. No.1. P.85-93.

Della Libera M., Passilongo D. \& Reby D. 2015. The acoustics of male rutting roars in the endangered population of Mesola red deer Cervus elaphus italicus // Mammalian Biology. Vol.80. P.395-400.

Desjonquères C., Rybak F., Ulloa J.S., Kempf A., Hen A.B. \& Sueur J. 2020. Monitoring the acoustic activity of an aquatic insect population in relation to temperature, vegetation and noise // Freshwater Biology. Vol.65. No.1. P.107-116.

Doohan B., Fuller S., Parsons S. \& Peterson E.E. 2019. The sound of management: Acoustic monitoring for agricultural industries // Ecological Indicators. Vol.96. P.739-746.

Douhard M., Bonenfant C., Gaillard J.-M., Hamann J.-L. \& Jacques M.G. 2013. Roaring counts are not suitable for the monitoring of red deer Cervus elaphus population abundance // Wildlife Biology. Vol.19. P.94-101.

Enari H., Enari H., Okuda K., Yoshita M., Kuno T. \& Okuda K. 2017. Feasibility assessment of active and passive acoustic monitoring of sika deer populations // Ecological Indicators. Vol.79. P.155-162.

Farina A. 2019. Ecoacoustics: a quantitative approach to investigate the ecological role of environmental sounds // Mathematics. Vol.7. No.1. P.21

Fedosenko A.K. 1980. [The Maral (Ecology, Behaviour, Management)]. Alma-Ata: Nauka. 200 p. [in Russian].

Feighny J.A., Williamson K.E. \& Clarke J.A. 2006. North American elk bugle vocalizations: male and female bugle call structure and context // Journal of Mammalogy. Vol.87. P.1072-1077.

Ferreira L.M., Oliveira E.G., Lopes L.C., Brito M.R., Baumgarten J., Rodrigues F.H. \& Sousa-Lima R.S. 2018. What do insects, anurans, birds, and mammals have to say about soundscape indices in a tropical savanna // Journal of Ecoacoustics. Vol.2. PVH6YZ.

Frey R., Volodin I.A., Volodina E.V., Carranza J. \& TorresPorras J. 2012. Vocal anatomy, tongue protrusion behaviour and the acoustics of rutting roars in free-ranging Iberian red deer stags (Cervus elaphus hispanicus) // Journal of Anatomy. Vol.220. P.271-292.

Frey R., Volodin I.A., Volodina E.V., Efremova K.O., Menges V., Portas R., Melzheimer J., Fritz G., Gerlach C. \& von Dörnberg K. 2020. Savannah roars: the vocal anatomy and the impressive rutting calls of male impala (Aepyceros melampus) - highlighting the acoustic correlates of a mobile larynx // Journal of Anatomy. Vol.36. No.3. P.398-424.
Fritz C.O., Morris P.E. \& Richler J.J. 2012. Effect size estimates: current use, calculations, and interpretation // Journal of Experimental Psychology. Vol.141. No.1. P.2-18.

García A.J., Landete-Castillejos T., Garde J.J. \& Gallego L. 2002. Reproductive seasonality in female Iberian red deer (Cervus elaphus hispanicus) // Theriogenology. Vol.58. No.8. P.1553-1562.

Gasc A., Francomano D., Dunning J.B. \& Pijanowski B.C. 2017. Future directions for soundscape ecology: The importance of ornithological contributions // Auk. Vol.134. P.215-228.

Golosova O.S., Volodin I.A., Isaeva I.L. \& Volodina E.V. 2017. Effects of free-ranging, semi-captive and captive management on the acoustics of male rutting calls in Siberian wapiti Cervus elaphus sibiricus // Mammalian Research. Vol.62. P.387-396.

Guinness F., Lincoln G.A. \& Short R.V. 1971. The reproductive cycle of the female red deer, Cervus elaphus L. // Reproduction. Vol.27. No.3. P.427-438.

Jeliazkov A., Bas Y., Kerbiriou C., Julien J.-F., Penone C. \& Le Viol I. 2016. Large-scale semi-automated acoustic monitoring allows to detect temporal decline of bush-crickets // Global Ecology and Conservation. Vol.6. P.208-218.

Kidjo N., Cargnelutti B., Charlton B.D., Wilson C. \& Reby D. 2008. Vocal behaviour in the endangered Corsican deer: description and phylogenetic implications // Bioacoustics. Vol.18. P.159-181.

Kumar V.P., Mukesh T., Rajpoot A., Joshi B.D., Nigam P., Ahmad K., Kumar D., Goyal S.P. 2017. Resolving the phylogenetic status and taxonomic relationships of the hangul (Cervus elaphus hanglu) in the family Cervidae // Mitochondrial DNA. Part A: DNA Mapping, Sequencing and Analysis. Vol.28. No.6. P.835-842.

Kuznetsova M.V., Danilkin A.A. \& Kholodova M.V. 2012. Phylogeography of red deer (Cervus elaphus): analysis of mtDNA cytochrome $b$ polymorphism // Biology Bulletin. Vol.39. No.4. P.323-330.

Kuznetsova M.V., Surjev V.I., Kolomejtsev S.G., Likhatskij J.P., Sipko T.P. \& Kholodova M.V. 2013. [Genetic status of red deer (Cervus elaphus) inhabiting Rostov region and some other regions of European part of Russia: results of a mitochondrial DNA investigation] // Vestnik Okhotovedeniya. Vol.10. No.1. P.53-65 [in Russian].

Letopis prirody 2017. [Number of mammals] // Letopis Prirody of Nature Reserve "Bolshekhekhtsirsky". Vol.48. P.180-184 [in Russian].

Liebers D., de Knijff P. \& Helbig A.J. 2004. The herring gull complex is not a ring species // Proceedings Biological Science B. Vol.271. No.1542. P.893-901.

Likhatskij J.P., Kolomejtsev S.G., Likhatskij E.J. \& Kulikov V.V. 2012. [The status of resources of European red deer and the effects of biotechnical measures on the population growth] // Kolomejtsev S.G. \& Likhatskij J.P. (eds.). [Materials of the Rostov State Experimental Game Facility]. No.1. Rostov-on-Don. P.120-153 [in Russian].

Lillis A., Caruso F., Mooney T.A., Llopiz J., Bohnenstiehl D. \& Eggleston D.B. 2018. Drifting hydrophones as an ecologically meaningful approach to underwater soundscape measurement in coastal benthic habitats // Journal of Ecoacoustics. Vol.2. STBDH1. 
Litvinov M.N. 2008. [Peculiarities of ruminant fauna development at the Nature Reserve "Ussuriisky"] // [Animal and Plant World of Far East]. Vol.11. P.127-131 [in Russian].

Ludt C.J., Schroeder W., Rottmann O. \& Kuehn R. 2004. Mitochondrial DNA phylogeography of red deer (Cervus elaphus)// Molecular Phylogenetics and Evolution. Vol.31. No.3. P.1064-1083.

Lunitsin V.G. \& Borisov N.P. 2012. [Deer Management for Velvet Antlers Production in Russia]. Barnaul: VNIIPO. 1000 p. [in Russian].

Mahmut H., Masuda R., Onuma M., Takahashi M., Nagata J., Suzuki M. \& Ohtaishi N. 2002. Molecular phylogeography of the red deer (Cervus elaphus) populations in Xinjiang of China: comparison with other Asian, European, and North American populations // Zoological Science. Vol.19. No.4. P.485-495.

Matrosova V.A., Ivanova A.D., Volodina E.V., Volodin I.A., Alexandrov D.Y., Sibiryakova O.V. \& Ermakov O.A. 2019. Phylogenetic relationship and variation of alarm call traits of populations of red-cheeked ground squirrels (Spermophilus erythrogenys sensu lato) suggest taxonomic delineation // Integrative Zoology. Vol.14. P.341-353.

Matrosova V.A., Rusin M.Y., Volodina E.V., Proyavka S.V., Savinetskaya L.E., Shekarova O.N., Rashevska H.V. \& Volodin I.A. 2016. Genetic and alarm call diversity across scattered populations of speckled ground squirrels (Spermophilus suslicus) // Mammalian Biology. Vol.81. P.255-265.

McComb K., Packer C. \& Pusey A. 1994. Roaring and numerical assessment in contests between groups of female lions, Panthera leo // Animal Behaviour. Vol.47. P.379-387.

McPherson F.J. \& Chenoweth P.J. 2012. Mammalian sexual dimorphism // Animal Reproduction Science. Vol.131. P.109-122.

Nikol'skii A.A., Pereladova O.B., Rutovskaja M.V. \& Formozov N.A. 1979. [The geographical variability of rut calls in red deer males] // Bulletin of Moscow Society of Naturalists. Vol.84. No.6. P.46-55 [in Russian].

Passilongo D., Reby D., Carranza J. \& Apollonio M. 2013. Roaring high and low: composition and possible functions of the Iberian stag's vocal repertoire // PLoS ONE. Vol.8. No.5. e63841.

Pepin D., Cargnelutti B., Gonzalez G., Joachim J. \& Reby D. 2001. Diurnal and seasonal variations of roaring activity of farmed red deer stags // Applied Animal Behavior Science. Vol.74. No.3. P.233-239.

Pérez-González J., Barbosa A.M., Carranza J. \& Torres-Porras J. 2010. Relative effect of food supplementation and natural resources on female red deer distribution in a Mediterranean ecosystem // Journal of Wildlife Management. Vol.74. No.8. P.1701-1708.

Pshenichnikova O.S., Klenova A.V., Sorokin P.A., Konyukhov N.B., Andreev A.V., Kharitonov S.P., Zubakin V.A., Artukhin Y.B. \& Schacter C.R. 2017. Population differentiation in whiskered auklets Aethia pygmaea: do diurnal and nocturnal colonies differ in genetics, morphometry and acoustics? // Journal of Avian Biology. Vol.48. P.1047-1061.

Pshenichnikova O.S., Klenova A.V., Sorokin P.A., Zubakin V.A., Konyukhov N.B., Kharitonov S.P. \& Artukhin Y.B. 2015. The crested auklet, Aethia cristatella
(Alcidae, Charadriiformes), does not vary geographically in genetics, morphology or vocalizations // Marine Biology. Vol.162. P.1329-1342.

Reby D., Andre-Obrecht R., Galinier A., Farinas G. \& Cargnelutti B. 2006. Cepstral coefficients and hidden Markov models reveal idiosyncratic voice characteristics in red deer (Cervus elaphus) stags // The Journal of the Acoustical Society of America. Vol.120. No.6. P.4080-4089.

Reby D. \& McComb K. 2003. Anatomical constraints generate honesty: acoustic cues to age and weight in the roars of red deer stags // Animal Behaviour. Vol.65. P.519-530.

Rusin I.Y., Volodin I.A., Andronova R.S. \& Volodina E.V. 2019. Passive acoustic monitoring of roaring activity in male wapiti Cervus elaphus xanthopygus at Far East of Russia: effects of recording site, temperature and time of day // Nature Conservation Research. Vol.4. No.3. P.34-44.

Sánchez-Prieto C.B., Carranza J. \& Pulido F.J. 2004. Reproductive behavior in female Iberian red deer: effects of aggregation and dispersion of food // Journal of Mammalogy. Vol.85. No.4. P.761-767.

Sibiryakova O.V., Volodin I.A. \& Volodina E.V. 2018. Advertising individual identity by mother and adolescent contact calls in Siberian wapiti Cervus elaphus sibiricus // Ethology. Vol.124. No.10. P.733-742.

Sitnikova E.F. \& Mishta A.V. 2006. [Fauna of mammals of the Bryansk region: list of species, distribution, population number] // Fedorov J.P. (ed.). [Studying and Conservation of Biological Diversity of the Bryansk Region. Materials on Management of Red Book of the Bryansk Region]. No.2. Trubchevsk: Kirillitsa. P.107-150 [in Russian].

Sitnikova E.F. \& Mishta A.V. 2008. [Mammals of the Reserve "Bryansk Forest"] // Fedorov J.P. \& Sitnikova E.F. (eds.). [Fauna of Vertebrate Animals of the Reserve "Bryansk Forest" (Birds, Mammals)]. Bryansk: Desyatochka. P.50-85 [in Russian].

Smith B.L. 1994. Out-of-season births of elk calves in Wyoming // Prairie Naturalist. Vol.26. No.2. P.131-136.

Struhsaker T.T. 1968. The behavior of the elk (Cervus canadensis) during the rut // Zeitschrift für Tierpsychologie. Vol.24. P.80-114.

Sugai L.S.M., Silva T.S.F., Ribeiro J.W.J.R. \& Llusia D. 2019. Terrestrial passive acoustic monitoring: review and perspectives // BioScience. Vol.69. No.1. P.15-25.

Towsey M., Znidersic E., Broken-Brow J., Indraswari K., Watson D.M., Phillips Y., Truskinger A. \& Roe P. 2018. Long-duration, false-colour spectrograms for detecting species in large audio datasets // Journal of Ecoacoustics. Vol.2. IUSWUI.

Trepet S.A. \& Eskina T.G. 2017. Modern dynamics of the red deer (Cervus elaphus maral) population in the Caucasian State Nature Reserve // Biology Bulletin. Vol.44. No.8. P.875-881.

Volodin I.A., Matrosova V.A., Volodina E.V., Garcia A.J., Gallego L., Márquez R., Llusia D., Beltrán J.F. \& LandeteCastillejos T. 2015a. Sex and age-class differences in calls of Iberian red deer during rut: reversed sex dimorphism of pitch and contrasting roars from farmed and wild stags // Acta Ethologica. Vol.18. P.19-29.

Volodin I.A., Nahlik A., Tari T., Frey R. \& Volodina E.V. 2019. Rutting roars in native Pannonian red deer of Southern Hungary and the evidence of acoustic divergence of male 
sexual vocalization between Eastern and Western European red deer (Cervus elaphus) // Mammalian Biology. Vol.94. P.54-65.

Volodin I.A., Sibiryakova O.V. \& Volodina E.V. 2016a. Sex and age-class differences in calls of Siberian wapiti Cervus elaphus sibiricus // Mammalian Biology. Vol.81. No.1. P.10-20.

Volodin I.A., Volodina E.V., Frey R., Carranza J. \& TorresPorras J. 2013a. Spectrographic analysis points to sourcefilter coupling in rutting roars of Iberian red deer // Acta Ethologica. Vol.16. P.57-63.

Volodin I.A., Volodina E.V., Frey R. \& Maymanakova I.L. 2013b. Vocal activity and acoustic structure of the rutting calls of Siberian wapiti (Cervus elaphus sibiricus) and their imitation with a hunting luring instrument // Russian Journal of Theriology. Vol.12. P.99-106.
Volodin I.A., Volodina E.V. \& Golosova O.S. 2016 b. Automated monitoring of vocal rutting activity in red deer (Cervus elaphus) // Russian Journal of Theriology. Vol.15. P.91-99.

Volodin I.A., Volodina E.V., Sibiryakova O.V., Naidenko S.V., Hernandez-Blanco J.A., Litvinov M.N. \& Rozhnov V.V. 2015b. Vocal activity and the acoustic structure of rutting calls in red deer in the Russian Far East // Doklady Biological Sciences. Vol.462. P.144-147.

Yen S.-C., Shieh B.-S., Wang Y.-T. \& Wang Y. 2013. Rutting vocalizations of Formosan sika deer Cervus nippon taiouanus - acoustic structure, seasonal and diurnal variations, and individuality // Zoological Science. Vol.30. No.12. P.1025-1031. 